\title{
Haematology, Carcass and Fatty Acid Composition of Finishing Broilers Fed Enzyme Supplemented Expeller Copra Meal in Corn-Animal Protein Diets
}

http://dx.doi.org/10.1590/1806-9061-2019-1126

-Author(s)

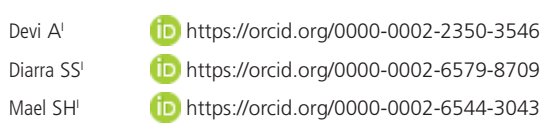

School of Agriculture and Food Technology, Alafua Samoa, University of the South Pacific.

\section{Mail Address}

Corresponding author e-mail address Siaka Seriba Diarra

School of Agriculture and Food Technology, Alafua Samoa, The University of the South Pacific, Samoa

Phone: +68521671275

Email: diarra_s@usp.ac.fj

\section{aKeywords}

Alternative ingredients, animal health, product quality.

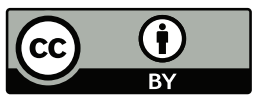

Submitted: 28/October/2019 Approved: 22/April/2020

\section{ABSTRACT}

This study analyzes the effect of different levels of expeller copra meal $(E C M)$ in animal protein-based diets with enzyme on the haematology, carcass and fatty acid composition of broilers. One hundred and sixty 20 days old Cobb broilers were assigned 8 different diets, 2 of them being controls and 6 others containing ECM at 150, 300 and $450 \mathrm{~g} /$ $\mathrm{kg}$, with or without enzymes. Four replicate cages of 5 birds each were fed the diets in a completely randomized design. Higher white blood cell (WBC) counts were obtained in chickens fed the control and 150 $\mathrm{g} / \mathrm{kg}$ ECM with enzyme $(p<0.05)$ diets. Meat saturated fatty acids (SFA) content increased on the $150 \mathrm{~g} / \mathrm{kg}$ diet and later decreased above 300 $\mathrm{g} / \mathrm{kg}$ without enzyme $(p<0.05)$. Monounsaturated fatty acid (MUFA) content was reduced with the inclusion of increasing ECM levels $(p<0.05)$. No interaction effect on polyunsaturated fatty acids (PUFA) was found. Main effects observed were MUFA and PUFA decrease with the inclusion of ECM in the diet $(p<0.05)$. Saturated fatty acid (SFA) content was found to increase on the $150 \mathrm{~g} \mathrm{ECM} / \mathrm{kg}$ diet and later to reduce with increasing ECM levels $(p<0.05)$. Enzyme supplementation reduced SFA and MUFA content $(p<0.05)$ but had no effect on PUFA ( $p>0.05$ ). In conclusion, inclusion of ECM up to $300 \mathrm{~g} / \mathrm{kg}$ in corn-animal protein diets has no adverse effects on most broiler haematological variables, but meat fatty acid composition may be altered. More research into basal diet composition, enzyme source and concentration is recommended.

\section{INTRODUCTION}

Poultry products are the main components of Fijians' diets, but high feed cost is a major factor affecting domestic production. Soybean meal, a conventional protein source, is in limited supply and expensive in the country. This calls for research into readily available alternative protein resources for poultry feeding. Expeller extracted copra meal $(E C M)$, a moderate protein source, is readily available in the country. Copra meal contains $150-250 \mathrm{~g} / \mathrm{kg}$ crude protein (Devi \& Diarra, 2017; Diarra et al., 2018; Devi \& Diarra, 2019). The high non-starch polysaccharides (NSP) content (420-610 g/kg) (Knudsen, 1997; Sundu et al., 2012; Devi \& Diarra, 2017) and low essential amino acid profile, especially lysine and methionine (Sundu et al., 2009; Devi \& Diarra, 2017; Devi \& Diarra, 2019), are major factors affecting the utilisation of ECM in poultry feeding. Dietary recommendations of ECM are variable, ranging from 50-300 g/kg (Sundu et al., 2006; Diarra et al., 2014; Devi \& Diarra, 2017) depending on the species, age and class of poultry. There have been studies on nutrient utilisation in broilers fed high fibre by-products using enzyme supplementation and probiotics (Sayehban et al., 2015; Sayehban et al., 2016; Seidavi et al., 2017; Woyengo 
et al., 2018; Head et al., 2019). Several techniques improve poultry ECM utilisation, such as amino acid and enzyme supplementation (Sundu et al., 2009; Diarra et al., 2014), diet composition (Devi \& Diarra, 2017), and processing methods (Sundu et al., 2009). The residual fat in ECM (35 to $120 \mathrm{~g} / \mathrm{kg}$; Ravindran \& Blair, 1992; Sundu et al., 2009; Devi \& Diarra, 2019) is a valuable energy source in the diet. However, ECM fat is mainly in the form of saturated fatty acids (NRC, 1994; DeMandal \& Mandal., 2011; Ghosh et al., 2014; Boateng et al., 2016). The effect of dietary fat sources on the fatty acid composition of poultry products is well documented (Carmona et al., 2006; Smink et al., 2010; Kanakri et al., 2018). Cherian (2011) fed fish and sunflower oils at $35 \mathrm{~g} / \mathrm{kg}$ in corn-soybean diets to broiler breeders and found increased long chain omega 3 and omega 6 fatty acids in the meat. Supplementation with enzymes (Raza et al., 2009; Anuradha \& Roy, 2015), amino acids (Kumar et al., 2016) and probiotics (FAO, 2016) is reported to improve poultry utilisation of high fibre diets. Raza et al. (2009) observed improved fibre digestibility in sunflower based diets supplemented with NIBGE enzyme. Devi and Diarra (2017) found that broilers can better utilize ECM when it is fed with animal proteins (fishmeal and meat with bone meal) than in soybean diets. Although diet composition is known to affect the fatty acid composition of poultry products (Cherian, 2016), the effect of feeding ECM in corn-animal protein-based diets on poultry meat fatty acid composition is not documented. This study investigated the effect of varying levels of ECM in corn-animal protein based diets with enzyme on haematology, carcass traits and fatty acid composition of broiler meat. The hypotheses were that feeding high ECM levels will not affect:
I. Some haematological parameters;
II. Carcass measurements; and
III. Fatty acid composition of broiler meat

\section{MATERIALS AND METHODS}

\section{Experimental site}

The study consisted of two experiments and was conducted at Ratish Poultry farm, Nausori, Fiji. The rainfall and air temperature in the study area during the experiment ranged from 765 to $1,093 \mathrm{~mm}$ and 25.8 to $27.4^{\circ} \mathrm{C}$, respectively (Fiji Meteorological Services, 2017). Expeller Copra Meal is readily available from Fiji Cooperative Dairy Company Limited located near the experimental farm. The research committee of the University of the South Pacific approved the experimental protocol.

\section{Experimental diets}

The proximate composition and amino acid profiles of protein sources were analyzed (Tables 1 and 2). Eight broiler finisher diets (200 g/kg CP) were formulated, consisting of two control diets without ECM and six diets based on 150, 300 and $450 \mathrm{~g} \mathrm{ECM} / \mathrm{kg}$ with and without enzymes (Table 3). The enzyme used for the study was Challenzyme 1309A, from Beijing Challenge Bio-Technology Company Limited, with 8 active components (amylase $500 \mathrm{U} / \mathrm{g}, \alpha$-galactosidase $100 \mathrm{U} / g$, B-glucanase $800 \mathrm{U} / g$, ß-mannanase $100 \mathrm{U} / g$, Cellulase $300 \mathrm{U} / g$, Protease $8000 \mathrm{U} / g$, Pectinase 500 $\mathrm{U} / \mathrm{g}$ and Xylanase $15000 \mathrm{U} / \mathrm{g}$ ).

Table 1 - Proximate composition, NDF and ADF (g/kg) and metabolisable energy $(\mathrm{MJ} / \mathrm{kg}$ ) of experimental protein sources.

\begin{tabular}{lccc}
\hline Constituents & \multicolumn{3}{c}{ Protein sources } \\
\cline { 2 - 4 } & FM & MBM & ECM \\
\hline ME (MJ/kg) & 11.31 & 13.44 & 10.88 \\
Dry matter & 725 & 879 & 887 \\
Crude protein & 531 & 481 & 184 \\
Ether extract & 106 & 253 & 120 \\
Ash & 117 & 144 & 49 \\
Crude fibre & 5 & 21 & 189 \\
NDF & 222 & 250 & 441 \\
ADF & 26 & 82 & 271 \\
NSP & - & - & 419 \\
\hline
\end{tabular}

ME: metabolisable energy (calculated); FM: fish meal; MBM: meat and bone meal; ECM: expeller copra meal, NSP: non-starch polysaccharides; NDF: Neutral Detergent Fibre; ADF: Acid Detergent Fibre

Table 2 - Amino acid composition of experimental protein sources (mg/100mg DM).

\begin{tabular}{lccc}
\hline Amino acid & \multicolumn{3}{c}{ Protein sources (mg/100mg) } \\
\cline { 2 - 4 } & $\mathrm{FM}$ & $\mathrm{MBM}$ & $\mathrm{ECM}$ \\
\hline Aspartic acid & 4.58 & 3.61 & 1.48 \\
Threonine & 2.16 & 1.67 & 0.56 \\
Serine & 2.13 & 1.90 & 0.79 \\
Glutamic acid & 6.68 & 5.63 & 3.12 \\
Proline & 2.84 & 3.20 & 0.62 \\
Glycine & 4.61 & 5.21 & 0.81 \\
Alanine & 3.44 & 3.16 & 0.80 \\
Valine & 2.27 & 1.95 & 0.89 \\
Isoleucine & 1.85 & 1.45 & 0.56 \\
Leucine & 3.46 & 2.87 & 1.10 \\
Tyrosine & 1.50 & 1.18 & 0.47 \\
Phenylalanine & 1.87 & 1.56 & 0.74 \\
Histidine & 1.50 & 1.26 & 0.39 \\
Lysine & 3.84 & 2.75 & 0.64 \\
Arginine & 3.29 & 3.12 & 2.35 \\
Cysteine & 0.36 & 0.25 & 0.28 \\
Methionine & 1.41 & 0.90 & 0.31 \\
Tryptophan & 0.46 & 0.30 & 0.15 \\
\hline
\end{tabular}

FM: fish meal; MBM: meat and bone meal; ECM: expeller copra meal; DM: Dry matter. 
Table 3 - Ingredient composition and calculated analysis ( $\mathrm{g} / \mathrm{kg}$, as fed basis) of finisher diets.

\begin{tabular}{|c|c|c|c|c|c|c|c|c|}
\hline \multirow[t]{3}{*}{ Ingredients ( $/ \mathrm{kg}$ ) } & \multicolumn{8}{|c|}{ Finisher diets } \\
\hline & \multicolumn{4}{|c|}{ ECM with no enzyme. } & \multicolumn{4}{|c|}{ ECM with enzyme. } \\
\hline & 0 & 150 & 300 & 450 & 0 & 150 & 300 & 450 \\
\hline Corn & 550.3 & 468.8 & 389.8 & 310.4 & 550.3 & 464.8 & 389.6 & 310.2 \\
\hline Wheat bran & 145.9 & 108.9 & 68.8 & 26.9 & 145.7 & 109.6 & 68.9 & 26.7 \\
\hline Fishmeal & 89.4 & 78.8 & 67.9 & 57.1 & 89.4 & 78.8 & 67.9 & 57.1 \\
\hline Meat \& bone & 158.8 & 137.5 & 116.9 & 98.5 & 158.7 & 140.5 & 116.7 & 98.6 \\
\hline Copra meal & 0 & 150 & 300 & 450 & 0 & 150 & 300 & 450 \\
\hline Coral sand & 30 & 30 & 30 & 30 & 30 & 30 & 30 & 30 \\
\hline Limestone & 19 & 19 & 19 & 19 & 19 & 19 & 19 & 19 \\
\hline *Premix & 2.5 & 2.5 & 2.5 & 2.5 & 2.5 & 2.5 & 2.5 & 2.5 \\
\hline Lysine & 0.8 & 1 & 1.5 & 2 & 0.8 & 1 & 1.5 & 2 \\
\hline Methionine & 0.3 & 0.5 & 0.6 & 0.6 & 0.3 & 0.5 & 0.6 & 0.6 \\
\hline Enzyme & - & - & - & - & 0.3 & 0.3 & 0.3 & 0.3 \\
\hline Salt & 3 & 3 & 3 & 3 & 3 & 3 & 3 & 3 \\
\hline \multicolumn{9}{|l|}{ Calculated analysis } \\
\hline Crude protein & 200 & 200 & 200 & 200 & 200 & 200 & 200 & 200 \\
\hline $\mathrm{ME}(\mathrm{MJ} / \mathrm{kg})$ & 12.19 & 12.34 & 12.51 & 12.68 & 12.19 & 12.28 & 12.50 & 12.67 \\
\hline Lysine & 11 & 11 & 10 & 10 & 11 & 11 & 10 & 10 \\
\hline Methionine & 5 & 5 & 4 & 4 & 5 & 5 & 4 & 4 \\
\hline
\end{tabular}

ECM: expeller copra meal; ME: metabolisable energy

*Premix (Vitamin and mineral) Bio-mix supplied/kg diet, vitamin A: 10000 IU, vitamin D3: 2000 IU, vitamin E: 23mg, niacin: 27.5mg, vitamin B1: 1.8 mg, B2: 5mg, B6: 3mg, B12: $0.015 \mathrm{mg}$, vitamin K: $3.2 \mathrm{mg}$, pantothenic acid: $7.7 \mathrm{mg}$, biotin: $0.06 \mathrm{mg}$, folic acid: $0.75 \mathrm{mg}$, choline chloride: $300 \mathrm{mg}$, cobalt: $0.2 \mathrm{mg}$, copper: $3 \mathrm{mg}$. iodine: $1 \mathrm{mg}$, iron: $20 \mathrm{mg}$, manganese: 40mg, selenium: $0.2 \mathrm{mg}$, zinc: $30 \mathrm{mg}$, anti-oxidant: $1.25 \mathrm{mg}$.

\section{Experimental broilers and management}

One hundred sixty-eight day-old Cobb 500 male broilers were purchased from Pacific Feeds Limited and brooded together for 7 days on commercial starter feed. They were placed over deep litter, feed and water were provided ad-libitum and continuous lighting was provided during the brooding phase. On the $8^{\text {th }}$ day, one hundred and sixty birds were individually weighed $(232.9 \pm 3.58 \mathrm{~g})$ and allocated to 32 cages $(65.5 \mathrm{~cm}$ x $50 \mathrm{~cm} \times 35.5 \mathrm{~cm}$ ) containing 5 birds each. Each experimental diet was fed to birds in 4 of the replicate cages. The poultry shed had East-West orientation and was open sided with mesh having dimensions (10 $\mathrm{m} \times 5 \mathrm{~m} \times 3 \mathrm{~m}$ ). After 2 days of adaptation to the cages, the birds were fed the experimental diets for 30 days (10-40 d) using factorial arrangement (4 ECM $\times 2$ enzymes). Diets and clean water were provided ad-libitum throughout the experimental period. The lighting programme consisted of $22 \mathrm{~h}$ light and $2 \mathrm{~h}$ dark. This was achieved by providing artificial lighting from the evening till night and switching it off 2 hours before daybreak.

\section{Data collection}

\section{Blood collection and analysis}

On day $35,1 \mathrm{ml}$ of blood was collected from the brachial vein of one bird per replicate using 23-gauge needles with $2 \mathrm{ml}$ sterile syringes. The samples were placed in clean, labelled heparinised tubes (BD Vacutainer) containing $1 \mathrm{mg}$ of Ethylene Diamine Tetra Acetic Acid (EDTA) powder as anti-coagulant. Collected blood samples were thoroughly mixed with the anti-coagulant and stored at a temperature of 4 ${ }^{\circ} \mathrm{C}$ for determination of packed cell volume (PCV), haemoglobin $(\mathrm{Hb})$ concentration, red blood cell (RBC) and white blood cell (WBC) counts following standard procedures at the Veterinary Pathology Laboratory, Nausori, Fiji. An automated haematology analyser, Exigo H400 system (Boule Medical ISO 13485 AB Domnarvsgatan 4 SE-163 53 Spanga, Sweden) was used to analyse WBC and RBC concentrations (cells/ $\mu l)$. Blood films were stained using Wright-Giemsa's staining method and total red and white blood cells were determined using an hemocytometer (Asian Scientific Instruments, ISO 9001: 2008, Hydrabad, India) with Natt \& Herrick's (1952) solution as diluting fluid (Campbell, 1994). The differential leukocyte and lymphocyte count smears were prepared, stained using Leishman technique and counted by separation under an optical microscope (Thrall \& Weiser, 2002). A micro haematocrit procedure (Thrall \& Weiser, 2002) by centrifuging capillary tube samples at $2500 \mathrm{rpm}$ for 5 mins was used to determine packed cell volume (PCV). The cyanmethemoglobin technique (Higgins \& Doumas, 2008) was used for determination of haemoglobin concentration. 


\section{Carcass measurements}

On the $40^{\text {th }}$ day, one bird per replicate was fasted overnight with water supply ad libitum. Early next morning, birds were euthanized by decapitation, scalded in water (at about $55^{\circ} \mathrm{C}$ ) for one minute, manually plucked and eviscerated. The eviscerated carcass was weighed using an electronic scale sensitive to $0.1 \mathrm{~g}$ and its value was expressed in relation to live weight. Dressing percentage was calculated as follows:

$$
\% \text { dressing }=\frac{\text { carcass weight }}{\text { live weight }} \times 100
$$

Carcass cuts (breast, thigh and drumstick) were also weighed and expressed as relative to live bird weights.

\section{Fatty acid composition of meat}

The breast meat samples were taken from the carcass measurements for total fats and fatty acid composition analysis. $100 \mathrm{~g}$ fresh breast meat samples were weighed, packed in labelled zip lock bags and taken to the laboratory of the Institute of Applied Sciences, University of the South Pacific, Laucala Campus.

Skinless fresh meat samples were freeze-dried, ground and stored at $-20^{\circ} \mathrm{C}$ until further analysis. Total fat was determined according to the AOAC (2012, ID 922.06) modified method. Total lipid determination was done gravimetrically using an analytical scale (Marte ${ }^{\circledR}$, sensitive to $0.001 \mathrm{~g}$ ). The fatty acid profile was determined using a Hewlett Packard $6890^{\circledR}$ gas chromatograph (Sukhija \& Palmquist, 1988). The carrier gas used was Helium at a $3.0 \mathrm{ml} / \mathrm{min}$ flow rate. The injection port and detector temperatures were set respectively at $200^{\circ} \mathrm{C}$ and $250{ }^{\circ} \mathrm{C}$. Oven temperature was set to $150{ }^{\circ} \mathrm{C}$ for $3 \mathrm{~min}$ and increased by $1.5^{\circ} \mathrm{C}$ every 3 min until it reached $190^{\circ} \mathrm{C}$. It was then increased at a rate of $1^{\circ} \mathrm{C} / \mathrm{min}$ up to a final temperature of 220 ${ }^{\circ} \mathrm{C}$. The retention times and peak area percentages were calculated using a Hewlett Packard computing integrator. Fatty acids were identified by comparing sample retention times with standard retention times (36 saturated, monounsaturated and polyunsaturated fatty acid standards, Sigma and Polyscience, U.S.A. ${ }^{\circledR}$ ). Quantification was carried out by normalization and transformation of the area percentage to $\mathrm{mg} / 100 \mathrm{~g}$ of edible portion, using Holland (1994) lipid conversion factor. The fatty acid composition of breast meat was calculated as:

Concentration $(\mathrm{mg} / \mathrm{g})=$ peak area of a given fatty acid $\times$ concentration of internal standard $(\mathrm{mg} / \mathrm{ml})$ / peak area of internal standard / sample weight (g).

\section{Statistical analysis}

Data collected were subjected to ANOVA (Steel and Torrie, 1980) of the GLM in SPSS (SPSS for Windows, version 22.0; IBM Corp., Armonk, NY, USA). Individual birds were the experimental units for weight gain, carcass and organ measurements and nutrient digestibility, whereas cages were the experimental units for feed intake. Treatment means comparison using the Least Significant Difference (LSD) and significant differences were reported at $5 \%$ level of probability.

\section{RESULTS}

\section{Haematological parameters}

Hematological study results (Table 4) showed no effects of the treatment on PCV, Hemoglobin and RBC $(p>0.05)$, but the WBC count was affected $(p<0.05)$. WBC value decreased in birds fed the $150 \mathrm{~g} / \mathrm{kg}$ diet when compared to the control $(p<0.05)$, but this was averted with enzyme addition ( $p>0.05)$. A lower WBC count was recorded in birds fed $300 \mathrm{~g} / \mathrm{kg}$ diets with enzyme and $450 \mathrm{~g} / \mathrm{kg}$ diets with and without enzyme when compared to other diets $(p<0.05)$. Higher WBC counts were recorded on control and $150 \mathrm{~g} \mathrm{ECM} /$ $\mathrm{kg}$ diets with enzyme when compared to the other ECM diets $(p<0.05)$. Main effects observed were that ECM level or enzyme supplementation did not affect observed hematological values ( $p>0.05$ ).

\section{Carcass traits}

The results of broilers' carcass studies are presented in Table 5. There were no significant interactions or main effects of ECM and enzyme supplementation on any of the carcass parameters studied ( $p>0.05)$.

\section{Fatty acid composition}

Results of fatty acid composition of broiler breast meat presented in Table 6 showed significant interaction effects on saturated fatty acids (SFA) and monounsaturated fatty acids (MUFA) $(p<0.05)$. The concentration of SFA decreased on the $300 \mathrm{~g} \mathrm{ECM} /$ $\mathrm{kg}$ with enzyme and $450 \mathrm{~g} / \mathrm{kg}$ diets. A lower meat MUFA content was observed on the $450 \mathrm{~g} / \mathrm{kg}$ with enzyme diet, but PUFA composition was unaffected ( $p>0.05)$. Main effects observed were that ECM level had significant effects on broiler meat fatty acid composition $(p<0.05)$. The highest SFA value was recorded on the $150 \mathrm{~g} / \mathrm{kg}$ diet and the lowest on the $450 \mathrm{~g} \mathrm{ECM} / \mathrm{kg}$ diet $(p<0.05)$. Mono unsaturated fatty acid (MUFA) and PUFA content was higher on the control $(p<0.05)$ and reduced with increasing copra meal levels $(p<0.05)$. Enzyme addition significantly 
Table 4 - Some haematological parameters of broiler chickens fed different ECM levels ( $\mathrm{g} / \mathrm{kg}$ ) with animal protein sources and enzyme supplementation.

\begin{tabular}{|c|c|c|c|c|c|c|}
\hline \multicolumn{2}{|l|}{ Treatment } & \multirow{2}{*}{$\begin{array}{c}\text { Feed intake } \\
(\mathrm{kg})\end{array}$} & \multirow{2}{*}{$\begin{array}{l}\mathrm{PCV} \\
(\%)\end{array}$} & \multirow{2}{*}{$\begin{array}{c}\text { WBC } \\
\left(\times 10^{9} / L\right)\end{array}$} & \multirow{2}{*}{$\begin{array}{l}\text { Hemoglobin } \\
(\mathrm{g} / \mathrm{dL})\end{array}$} & \multirow{2}{*}{$\begin{array}{c}\mathrm{RBC} \\
\left(\times 10^{12} / \mathrm{L}\right)\end{array}$} \\
\hline Copra & Enzyme & & & & & \\
\hline \multirow[t]{2}{*}{0} & No & $19.66^{a}$ & 37.75 & $69.05^{a}$ & 13.63 & 2.31 \\
\hline & Yes & $20.15^{a}$ & 43.75 & $66.17^{a}$ & 14.50 & 2.48 \\
\hline \multirow[t]{2}{*}{150} & No & $18.93^{a}$ & 33.25 & $53.23^{b}$ & 14.33 & 2.29 \\
\hline & Yes & $19.25^{a}$ & 39.25 & $64.30^{a}$ & 13.33 & 2.12 \\
\hline \multirow[t]{2}{*}{300} & No & $16.86^{b}$ & 36.50 & $44.30^{b}$ & 14.03 & 2.29 \\
\hline & Yes & $19.01^{\mathrm{a}}$ & 40.25 & $27.43^{c}$ & 14.63 & 2.45 \\
\hline \multirow[t]{2}{*}{450} & No & $17.54^{\mathrm{ab}}$ & 40.75 & $35.35^{c}$ & 13.73 & 2.17 \\
\hline & Yes & $16.57^{b}$ & 40.75 & $30.02^{c}$ & 14.73 & 2.28 \\
\hline SEM & & 0.509 & 2.941 & 2.983 & 0.815 & 0.159 \\
\hline \multicolumn{7}{|l|}{ Main effects } \\
\hline \multicolumn{7}{|l|}{ Copra } \\
\hline 0 & & $19.90^{\mathrm{a}}$ & 40.75 & 67.61 & 14.06 & 2.39 \\
\hline 150 & & $19.09^{a}$ & 36.25 & 58.76 & 13.83 & 2.21 \\
\hline 300 & & $17.93^{b}$ & 38.38 & 35.86 & 14.33 & 2.37 \\
\hline 450 & & $17.06^{b}$ & 40.75 & 17.68 & 14.23 & 2.22 \\
\hline \multicolumn{7}{|l|}{ Enzyme } \\
\hline No & & 18.25 & 37.06 & 50.48 & 13.93 & 2.26 \\
\hline Yes & & 18.74 & 41.00 & 39.47 & 14.29 & 2.33 \\
\hline \multicolumn{7}{|l|}{ Probabilities } \\
\hline Copra & & 0.000 & 0.374 & 0.151 & 0.933 & 0.542 \\
\hline Enzyme & & 0.179 & 0.070 & 0.505 & 0.528 & 0.551 \\
\hline Copra*Enzyme & & 0.043 & 0.710 & 0.014 & 0.592 & 0.680 \\
\hline
\end{tabular}

PCV: Packed Cell Volume; WBC: White Blood Cells; RBC: Red Blood Cells; SEM: Standard Error of Mean. a, b, c: values within the column with different superscripts differ significantly ( $p=0.05)$.

Table 5 - Relative weights of carcass and commercial cuts (\% live weight) of broilers fed different ECM levels ( $\mathrm{g} / \mathrm{kg}$ ) with animal protein sources and enzyme supplementation.

\begin{tabular}{|c|c|c|c|c|c|}
\hline \multicolumn{2}{|l|}{ Treatment } & \multirow{2}{*}{ Dressing } & \multirow{2}{*}{ Breast } & \multirow{2}{*}{ Thigh } & \multirow{2}{*}{ Drumstick } \\
\hline Copra & Enzyme & & & & \\
\hline \multirow[t]{2}{*}{0} & No & 72.92 & 21.89 & 10.65 & 9.73 \\
\hline & Yes & 74.37 & 23.66 & 11.80 & 11.07 \\
\hline \multirow[t]{2}{*}{150} & No & 73.29 & 20.52 & 11.34 & 10.86 \\
\hline & Yes & 71.62 & 20.45 & 10.66 & 10.91 \\
\hline \multirow[t]{2}{*}{300} & No & 69.18 & 19.13 & 10.65 & 10.38 \\
\hline & Yes & 73.89 & 22.19 & 11.29 & 10.19 \\
\hline \multirow[t]{2}{*}{450} & No & 71.78 & 20.50 & 11.46 & 10.48 \\
\hline & Yes & 72.02 & 19.14 & 10.87 & 11.80 \\
\hline SEM & & 1.338 & 1.145 & 0.433 & 0.548 \\
\hline \multicolumn{6}{|l|}{ Main effects } \\
\hline \multicolumn{6}{|l|}{ Copra } \\
\hline 0 & & 73.64 & 22.78 & 11.23 & 10.40 \\
\hline 150 & & 72.45 & 20.49 & 11.00 & 10.88 \\
\hline 300 & & 71.53 & 20.66 & 10.97 & 10.29 \\
\hline 450 & & 71.90 & 19.82 & 11.16 & 11.14 \\
\hline \multicolumn{6}{|l|}{ Enzyme } \\
\hline No & & 71.79 & 20.51 & 11.03 & 10.36 \\
\hline Yes & & 72.97 & 21.36 & 11.16 & 10.99 \\
\hline \multicolumn{6}{|l|}{ Probabilities } \\
\hline Copra & & 0.433 & 0.084 & 0.921 & 0.375 \\
\hline Enzyme & & 0.223 & 0.304 & 0.672 & 0.118 \\
\hline Copra*Enzyme & & 0.140 & 0.250 & 0.114 & 0.369 \\
\hline
\end{tabular}

SEM: Standard Error of Mean.
Table 6 - Breast meat fatty acid composition ( $\mathrm{g} / 100 \mathrm{~g})$ of broilers fed different ECM levels $(\mathrm{g} / \mathrm{kg}$ ) with animal protein sources and enzyme supplementation.

\begin{tabular}{|c|c|c|c|c|}
\hline \multicolumn{2}{|l|}{ Treatment } & \multirow{2}{*}{ SFA } & \multirow{2}{*}{ MUFA } & \multirow{2}{*}{ PUFA } \\
\hline Copra & Enzyme & & & \\
\hline \multirow[t]{2}{*}{0} & No & $0.69^{b c}$ & $0.70^{a}$ & 0.24 \\
\hline & Yes & $0.64^{c}$ & $0.71^{a}$ & 0.32 \\
\hline \multirow[t]{2}{*}{150} & No & $1.19^{a}$ & $0.58^{b}$ & 0.23 \\
\hline & Yes & $1.00^{a}$ & $0.52^{b}$ & 0.15 \\
\hline \multirow[t]{2}{*}{300} & No & $0.91^{\mathrm{ab}}$ & $0.42^{c}$ & 0.12 \\
\hline & Yes & $0.34^{d}$ & $0.39^{c}$ & 0.12 \\
\hline \multirow[t]{2}{*}{450} & No & $0.55^{\mathrm{cd}}$ & $0.40^{c}$ & 0.12 \\
\hline & Yes & $0.13^{d}$ & $0.18^{d}$ & 0.09 \\
\hline SEM & & 0.084 & 0.032 & 0.034 \\
\hline \multicolumn{5}{|l|}{ Main effects } \\
\hline \multicolumn{5}{|l|}{ Copra } \\
\hline 0 & & $0.66^{b}$ & $0.71^{\mathrm{a}}$ & $0.28^{a}$ \\
\hline 150 & & $1.09^{a}$ & $0.55^{b}$ & $0.19^{b}$ \\
\hline 300 & & $0.63^{b}$ & $0.40^{c}$ & $0.12^{b c}$ \\
\hline 450 & & $0.34^{c}$ & $0.29^{d}$ & $0.11^{c}$ \\
\hline \multicolumn{5}{|l|}{ Enzyme } \\
\hline No & & $0.83^{\mathrm{a}}$ & $0.52^{\mathrm{a}}$ & 0.18 \\
\hline Yes & & $0.53^{b}$ & $0.45^{b}$ & 0.17 \\
\hline \multicolumn{5}{|l|}{ Probabilities } \\
\hline Copra & & 0.000 & 0.000 & 0.000 \\
\hline Enzyme & & 0.000 & 0.004 & 0.776 \\
\hline Copra*Enzyme & & 0.021 & 0.008 & 0.135 \\
\hline
\end{tabular}

SFA: Saturated Fatty Acids; MUFA: Monounsaturated Fatty Acids; PUFA: Polyunsaturated Fatty Acids; SEM: Standard Error of Mean; a, b, c: values within the column with different superscripts differ significantly $(p=0.05)$. 
reduced SFA and MUFA compositions $(p<0.05)$ but did not affect breast meat PUFA composition ( $p>0.05$ ).

\section{DISCUSSION}

\section{Haematological parameters}

Blood profiles is a good assessment of nutritional and health status. Improved feed intake and protein digestibility on the $150 \mathrm{~g} / \mathrm{kg}$ ECM diet could be reasons for higher WBC count in the present study. The beneficial effect of mannan fibre on gut health is well reported (Sundu et al., 2012; Putri et al., 2017). Putri et al. (2017) observed higher leukocyte counts in broilers fed a $0.35 \mathrm{~g}$ ECM mannan oligosaccharides per kg diet when compared to control and antibiotic supplemented diets. Similarly, Konca et al. (2009) reported no effect of commercial mannan oligosaccharides on turkeys' blood profile. Fernandez et al. (2002) found higher leukocyte counts and improved immune responses in broilers fed mannan containing palm kernel cake diets. The short chain fatty acids (SCFA) produced from caecal fermentation of complex fibres improve gut health by suppressing harmful bacteria and improving bird immune responses. Decreasing levels of WBC counts were observed with increasing levels of ECM. The lower WBC count observed in this experiment despite the higher feed intake on the $300 \mathrm{~g} / \mathrm{kg}$ ECM diet with enzyme could not be explained. The activities of several enzymes in Challenzyme 1309A may also affect WBC counts.

\section{Carcass traits}

There were no interactions or main effects of ECM and enzyme addition on relative weights of carcass and cuts (breast, thigh and drumstick). This may suggest that all diets met bird requirements for muscle development. Devi \& Diarra (2017) found no effects of $150 \mathrm{~g} / \mathrm{kg}$ dietary ECM in corn-animal protein diets on thigh and drumstick yields. Contrary to the findings of this study, however, Diarra et al. (2014) observed reduced dressing percentage and breast weights in finishing broilers fed cassava-ECM diets when compared to control commercial feed. As mentioned earlier, differences in feed processing and basal diet composition are all possible factors affecting poultry ECM utilisation.

\section{Fatty acid composition}

The lower SFA in the interaction effects on the 450 $\mathrm{g} \mathrm{ECM} / \mathrm{kg}$ diet despite the higher SFA in ECM (Ghosh et al., 2014) may be due to lower intake of this diet. The effect of dietary fat on fatty acid composition of poultry products is well documented. Cherian (2011) fed broiler breeders fish and sunflower oils at $35 \mathrm{~g} / \mathrm{kg}$ in corn-soybean diets and found increased long chain omega 3 and omega 6 fatty acids in the meat. The author attributed the pattern of breast muscle fatty acid composition to the diet's fatty acid profile, confirming that poultry has a limited ability to transform dietary fat. There are reports of fatty acids manipulation in meat and eggs using dietary fat, alteration in production practices, antioxidants including vitamin $\mathrm{E}$ and ginseng (Hargis \& Elswyk, 1993; Wood \& Enser, 1997; Yan et al., 2011; Cherian, 2016; Head et al., 2019). Wood \& Enser (1997) observed quick poultry meat response to dietary concentrations of linoleic, linolenic and total PUFA. Yan et al. (2011) found that ginseng root meal inclusion in laying hen diets reduced SFA and increased PUFA in bird egg yolk and attributed this to the PUFA and lower SFA in ginseng root meal. Panaite et al. (2019) recommended $50 \mathrm{~g}$ dried tomato waste with flaxseed / kg corn-soybean diets in laying hens for maximum n-3 (PUFA) fatty acids in eggs. In another study, Thacker \& Widyaratne (2012) recommended $150 \mathrm{~g} / \mathrm{kg}$ camelina meal for total $\mathrm{n}-3$ and $\mathrm{n}-6$ (PUFA) deposition in broiler meat. Contrary to our findings, Farias et al. (2019) observed that up to $250 \mathrm{~g}$ stored $\mathrm{ECM} / \mathrm{kg}$ in corn-soybean diets did not alter fatty acid composition in quails. Similarly, Kim et al. (2001) found no effect of ECM on fatty acid composition of finishing pigs at $40 \mathrm{~g} / \mathrm{kg}$ in corn-soybean based diets. The source and intake of dietary fat and the class, age and species of poultry may all affect the fatty acid composition of poultry products. Lower SFA despite higher intake on the $300 \mathrm{~g} / \mathrm{kg}$ diet with enzyme was not explained and needs to be investigated.

\section{CONCLUSION}

In conclusion, inclusion of ECM up to $300 \mathrm{~g} /$ $\mathrm{kg}$ in corn-animal protein diets without enzyme has no adverse effects on most broilers' hematological variables. Enzyme supplementation maintains meat fatty acid quality in term of PUFA, but MUFA decreases with the dietary ECM level regardless of enzyme addition. Future research into basal diet compositions, enzyme sources and concentrations that reduce production cost and maintain a healthy fatty acid profile is recommended.

\section{ACKNOWLEDGEMENTS}

The research was financially supported by the University of the South Pacific (Grant No. F5136 RI001- 
ACT-PROG). Prof. Ravindran of Massey University, New Zealand, is acknowledged for assisting with chemical analysis of the feed ingredients. Research facilities and space were available at Ratish Chandra's farm.

\section{CONFLICT OF INTEREST STATEMENT}

\section{The authors declare no conflict of interest.}

\section{REFERENCES}

Anuradha P, Roy B. Effect of supplementation of fiber degrading enzymes on performance of broiler chickens fed diets containing de-oiled rice bran. Asian Journal of Animal and Veterinary Advances 2015;10:179184.

Boateng L, Ansong R, Owusu, WB, Steiner-Asiedu M. Coconut oil and palm oil's role in nutrition, health and national development:A review. Ghana Medical Journal 2016;50(3):189-196.

Campbell TW. Haematology. In: Ritchie BW, Harrison GJ, Harrison LR, editors Avian medicine: principles and application. Lake Worth: Wingers Publishers Incorporated; 1994. p.176-198.

Carmona JM, Rey Muñoz Al, Sanz M, López Bote CJ. Effect of dietary fat on fatty acid composition and fat and meat texture properties in broilers. Archiv fur Geflugelkunde 2006;70(4):174-180.

Cherian G. Essential fatty acids and early life programming in meat-type birds. World Poultry Science Journal 2011;67:599-614.

Cherian G. Dietary manipulation of poultry to develop value-added functional foods for humans. Proceedings of the NZ Poultry Industry Conference; 2016 Oct 4-5; Wellington. New Zealand; 2016.

De Mandal M, Mandal S. Coconut (Cocos nucifera L:Arecaceae):In health promotion and disease prevention. Asian Pacific Journal of Tropical Medicine 2011;4(3):241-247.

Devi A, Diarra SS. Influence of dietary protein source and utilisation of copra meal in finishing broiler chicken. Indian Journal of Animal Nutrition 2017;34(2):193-200

Devi A, Diarra SS. Maximum utilisation of available resources for efficient poultry feeding in the South Pacific:major issues and prospects. World Poultry Science Journal 2019;75:219-234.

Diarra SS, Kolubalona JK, Lal PP, Stewart E, Teine MA, Havea T, et al. A Comparative utilisation of high dietary copra and palm kernel cakes based diets with exogenous enzyme by young pullets and layers. Indian Journal of Animal Nutrition 2018;35(3):339-344.

Diarra SS, Sandakabatu D, Perera D, Tabuaciri P, Mohammed U. Growth performance and carcass yield of broiler chickens fed commercial finisher and cassava copra meal-based diets. Asian Journal of Poultry Science 2014;8(1):16-22

FAO. Probiotics in animal nutrition. Production, impact and regulation [paper, 179]. In: Yadav SB, Athol VK, Peter JD, Wayne LB. Rome: FAO Animal Production and Health; 2016.

Farias NNP, Freitas ER, do Nascimento GAJ, Xavier RPS, de Melo Braz N, Dantas FDT, et al. Fresh and stored copra meal in meat quail diets. Tropical Animal Health and Production 2019;51(1):179-185.

Fernández J, Navasa $M$, Gomez J. Bacterial infections in cirrhosis:epidemiological changes with invasive procedures and norfloxacin prophylaxis. Hepatology 2002;35:140-148.
Ghosh P K, Bhattacharjee P, Mitra S, Poddar-Sarkar M. Physicochemical and phytochemical analyses of copra and oil of Cocos nucifera L. (West Coast Tall Variety). International Journal of Food Science 2014;2014:1-8.

Hargis P S, Van Elswyk ME. Manipulating the fatty acid composition of poultry meat and eggs for the health conscious consumer. World's Poultry Science Journal 1993;49:251-264.

Head B, Bionaz M, Cherian, G. Flaxseed and carbohydrase enzyme supplementation alters hepatic n-3 polyunsaturated fatty acid molecular species and expression of genes associated with lipid metabolism in broiler chickens. Veterinary Sciences 2019;6(1):25.

Higgins TBE, Doumas BT. Measurement of haemoglobin in blood. In: Burtis CA, Ashwood ER, Bruns DE, editors. Tietz Fundamentals of clinical chemistry. $6^{\text {th }}$ ed. Philadelphia: Saunders Elsevier; 2008. p.514-515.

Holland B, Welch AA, Unwin ID, Buss DH, Paul AA, Southgate DAT, editors. McCance and widdowson's: the composition of foods. London: The Royal Society of Chemistry; 1994

Kanakri K, Carragher J, Hughes R, Muhlhausler B, Gibson R. The effect of different dietary fats on the fatty acid composition of several tissues in broiler chickens. European Journal of Lipid Science and Technology 2018;120:1-13.

Kim BG, Lee JH, Jung HJ, Han YK, Park KM, Han, I.K. Effect of partial replacement of soybean meal with palm kernel meal and copra meal on growth performance, nutrient digestibility and carcass characteristics of finishing pigs. Asian-Australasian Journal of Animal Science $2001 ; 14(6): 821-830$

Knudsen KEB. Carbohydrate and lignin contents of plant materials used in animal feeding. Animal Feed Science and Technology 1997;67:319338

Konca Y, Kirkpinar F, Mert S, Kayhan B. Performance, intestinal microflora, and blood constituents in finishing turkeys fed diets supplemented with dietary mannan oligosaccharide and live yeast. Journal of Animal Feed Science 2009;18:508-517.

Kumar CB, Gloridoss RG, Singh KC, Prabhu TM, Suresh BN. Performance of broiler chickens fed low protein, limiting amino acid supplemented diets formulated either on total or standardized ileal digestible amino acid basis. Asian-Australasian Journal of Animal Science 2016;29(11):16161624.

Natt PM, Herrik CA. A new blood diluent for counting the erythrocytes and leucocytes of chicken. Poultry Science 1952;31:735-738.

NRC - National Research Council. Nutrient requirements of poultry. $9^{\text {th }}$ ed. Washington; 1994.

Panaitea TD, Nour V, Vlaicua PA, Ropotaa M, Corbuc AR, Saracila M. Flaxseed and dried tomato waste used together in laying hens diet. Archives of Animal Nutrition 2019;73(3):222-238

Putri N, Sumiati S, Meryandini A. Effect of dietary mannan-oligosaccharides from copra meal on intestinal microbes and blood profile of broiler chickens. Journal of the Indonesian Tropical Animal Agriculture 2017:42(2):109-119.

Ravindran V, Blair R. Feed resources for poultry production in Asia and the Pacific. 11. Plant protein sources. World's Poultry Science Journal $1992 ; 48: 205-231$

Raza S, Ashraf M, Pasha TN, Latif F. Effect of enzyme supplementation of broiler diets containing varying level of sunflower meal and crude fibre. Pakistan Journal of Botany 2009;41(5):2543-2550.

Sayehban P, Seidavi A, Dadashbeiki M, Ghorbani A, Araújo WAG, Albino LFT. Effects of different dietary levels of two types of olive pulp and exogenous enzyme supplementation on the gastrointestinal tract size, immunology and hematology of broilers. Brazilian Journal of Poultry Science 2015;17:73-85. Special 
Sayehban P, Seidavi A, Dadashbeiki M, Ghorbani A, Araújo WAG, Albino LFT. Effects of different levels of two types of olive pulp with or without exogenous enzyme supplementation on broiler performance and economic parameters. Brazilian Journal of Poultry Science 2016;18(3):489-499

Seidavi AR, Dadashbeiki M, Alimohammadi-Saraei MH, Van Den Hoven R, Laudadio $\mathrm{V}$, Tufarelli $\mathrm{V}$. Effects of dietary inclusion level of a mixture of probiotic cultures and enzymes on broiler chickens immunity response. Environmental Science and Pollution Research 2017;24(5):4637-4644.

Smink W, Gerrits WJJ, Hovenier R, Geelen MJH,Verstegen MWA, Beynen $A C$. Effect of dietary fat sources on fatty acid deposition and lipid metabolism in broiler chickens Poultry Science 2010;89(11):24322440.

Steel RGD, Torrie JH. Principles and procedures of statistics. A biometrical approach. $2^{\text {nd }}$ ed. New York: McGraw Hills Book; 1980.

Sukhija PS, Palmquist DL. Rapid method for determination of total fatty acid content and composition of feedstuffs and faeces. Journal of Agriculture and Food Chemistry 1988;36:1202-1206.

Sundu B, Kumar A, Dingle J. Response of broiler chicks fed increasing levels of copra meal and enzymes. International Journal of Poultry Science 2006:5(1):13-18.

Sundu B, Kumar A, Dingle J. Feeding value of copra meal for Broilers. World Poultry Science Journal 2009;65:481-491.
Sundu B, Hatta $U$, Chaudhry AS. Potential of beta-mannan from copra meal as feed additive for broilers. World's Poultry Science Journal 2012;68:707-716

Thacker P, Widyaratne G. Effects of expeller pressed camelina meal and/or canola meal on digestibility, performance and fatty acid composition of broiler chickens fed wheat-soybean meal-based diets. Archives of Animal Nutrition 2012;66(5):402-15.

Thrall MA, Weiser MG. Haematology. In: Hendrix CM, editor. Laboratory procedures for veterinary technicians. $4^{\text {th }}$ ed. Missouri: Mosby Incorporated; 2002. p.29-74.

Wood JD, Enser M. Factors influencing fatty acids in meat and the role of antioxidant in improving meat quality. British Journal of Nutrition $1997 ; 78(1): 49-60$

Woyengo TA, Bogota KJ, Noll SL, Wilson J. Enhancing nutrient utilization of broiler chickens through supplemental enzymes. Poultry Science 2018;98(3):1302-1309.

Yan L, Meng QW, Ao X, Wang JP, Jang HD, Kim IH. Evaluation of dietary wild-ginseng adventitious root meal on egg production, egg quality, hematological profiles and egg yolk fatty acid composition in laying hens. Livestock Science 2011;140:201-205. 